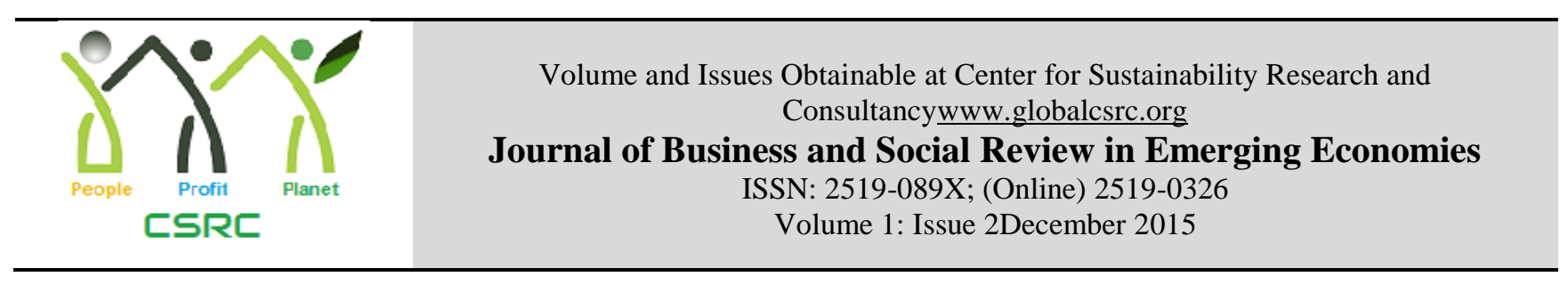

\title{
Violation of Consumer Rights by Electronic Media through Advertisements
}

\author{
${ }^{1}$ Ghulam Safdar, ${ }^{2}$ Ghulam Shabir, ${ }^{3}$ Abdul Wajid Khan \\ ${ }^{1}$ Ph.D Scholar, Department of Media Studies, The Islamia University of Bahawalpur, Pakistan \\ safdarsting@gmail.com \\ ${ }^{2}$ Professor, Department of Media Studies, The Islamia University of Bahawalpur, Pakistan \\ drshabair@yahoo.com \\ ${ }^{3}$ Ass. Professor, Department of Media Studies, The Islamia University of Bahawalpur, Pakistan \\ dr.abdulwajid@yahoo.com
}

\begin{tabular}{|c|c|}
\hline ARTICLEDETAILS & ABSTRACT \\
\hline History & This research paper attempts to evaluate the consumer rights and their \\
\hline RevisedFormat:Nov 2015 & violation by electronic media through advertisement. This is \\
\hline AvailableOnline: Dec 2015 & misguiding the consumer to buy harmful and unnecessary products. \\
\hline & This research also aims at interpolating and ascertaining the onus of \\
\hline Keywords & responsibility of a responsible media with regards to advertising. In \\
\hline Consumer & the recent past the principle of "Caveat Emptor" which meant \\
\hline Advertisement & "Buyers beware" governed the relationship between a seller and \\
\hline Violation of Rights & buyer. In the era of open markets the buyer and seller came face to \\
\hline Electronic Media Legislation & $\begin{array}{l}\text { face, seller exhibited his goods, and buyer thoroughly examined them } \\
\text { and then purchased them. The assumption would be consumer would }\end{array}$ \\
\hline JEL Classification: & use all his care and skill while entering into a transaction. The buyer \\
\hline$D 18, M 37, J 83$ & $\begin{array}{l}\text { to examine the goods beforehand and most of the transactions are } \\
\text { now concluded by correspondence. Discussion on consumer's rights } \\
\text { and their violation by media through advertisements is suggestive } \\
\text { that consumers today enjoy a good amount of legal protection. But, } \\
\text { even today, a large number of us remain exploited. }\end{array}$ \\
\hline
\end{tabular}

(C) 2015 The authors, under a Creative Commons Attribution-

NonCommercial 4.0

\section{Introduction}

In the present age, electronic media has powerful affects on consumer. It informs the consumer about the importance of any product. But it hesitates to highlight the negative impact of product. Due to this factor, consumer rights are damaged by the electronic media through advertising.

*Corresponding author'semail address:safdarsting@gmail.com

Recommended citation:Safdar, G., Shabir, G., Khan, A.W. (2015). Violation of Consumer Rights by Electronic Media through Advertisements. Journal of Business and Social Review in Emerging Economies, 1 (2) 69-76DOI: 
In critical role of media advertising as affecting consumers are defined as a negative situation where there is little or no control on the part of producer or retailer. (Dutton and Jackson, 1987; Clark, 1988). The event can be the result of bad judgment calls and mistakes made by management and/or during manufacturing (Mitchell, 1986); faults in the product itself (Tory, 1993).

However, the large flow of marketing literature in the present age offers models for advertisement or other means of communication for changing the perception of consumers. In the present age, a new concept of marketing has come. Now media is playing the role as third party between seller and buyers relationship (Assael, 1992).

\section{Literature Review}

Nilson (1995) describe media has changed the market condition at world level. He states that media has strong influence and ability to change the perceptions and behavior of consumer and have strong tools that effect on the consumer market. The basic aim of this paper is to find out the influence of media on the exchange in consumer-vendor relationship. This study will cover that how media effect the consumer when they are suddenly informed the media and consumer fallow up that things which are presented in the advertisement.

Booth (1993) states in his book Crises Management Strategies that international market has given the better opportunities to firms and industries to played important role through media. Its reality that media has strong impact on consumer's behavior, vendors and producers. The role of media in changing the behavior of the consumers in advertising activities has been less researched.

Richins (1983), Day and London (1976), and Diamond et al. (1976) highlight that there is not so much studies has been taken on the change of consumer perception from satisfaction to dissatisfaction. Richins (1983) choose to study the negative role of media in the view of word-tomouth that how the consumer perceive a news event during social interactions between consumers.

Keane (1991) put the light on the media responsibility about advertising marketing that role of media in marketing products is doubtful, because media advertising material can affect the position of company positively and negatively at the same time. Media act as according to the demand of some business players and can affect positive and negative on the behviour of consumers. It can also undertake a neutral position when spreading the news or even create the 
impression of an impending crisis and change a negative perception the public ight have of a company or product into a positive one and vice versa.

\subsection{Mythical Concept of Tobacco}

The process of buying is incomplete without the buyer. It is pertinent to note that a buyer is always primarily considered the most vital guest on our premises. We rely on the buyer. The consumer is not for us a trouble as is popularly thought as the trade exists just because of him or her. We should consider this or her act of his or her to be a favour upon our business. It should be kept in mind that this or her act of kindness is made to the end user by giving him or her chance to further his or her business. A favour is being done by him or her by giving us the prospect to provide for him or her. This or her act of his or her is a favour which is not unessential in the least.

Being a consumer in Pakistan is not an easy thing. It involves being fleeced by greedy and profit hungry people present in the market. All of us are basically consumers and every day we when we go out of our homes we procure commodities or services we engage in the buying process. Whilst buying commodities or services our basic concern in with our wealth, wellbeing, security, surroundings etc. in general we should consider that we are at all times in a seller bazaar that is because of the deception given by advertisements on the media to the consumers. The consumers thus also are aware of the result at the receiving end; to a large extent it is true also. The purchasers being the weaker party in the profit-making dealings are either both taken for granted or taken for a rid. The law then comes into play to take away the unfair advantage gained by the producers. How effective is law this however a different story all together.

Swindling the purchaser has turned out to be so rampant that no one remains unscathed by this or her woe. Fake or ambiguous advertisements or appearances, bargain value, presenting gifts, awards, competition etc, and the victims are deprived by means knowingly or unknowingly. Every day the consumer is pitted against a spate of advertisements on the idiot box in our lives, at the streets on the radio at all nooks and corners of our lives. It is not possible for the consumer to remain oblivious of this or her phenomenon despite even his or her best efforts.

It is pertinent to note that we have to cater for the down trodden weak consumer and to give him or her respite from the evil clutches of the producers. It is a deceived. Other than that there is an extra side of this or her picture as well, along with this or her intention is also a lack of awareness, lack of a sense of accountability and unwarranted feelings of vulnerability on our part being a consumer. The majority of us consider that we usually act sensibly. The pseudo logic which drives our lives makes us feel comforted on every purchase we incur. We perceive ourselves as being quite-well versed in our social trends or business tactics although in actuality it is not so. Our performance during buying is often unreasonable, prejudiced by social trends, sale pressure, and advertisements. Consequently often our purchases of goods or services are 
conducted without paying adequate attention being given to price and quality. Many of us do not comprehend the ecological cost of our consumption. The fact that we are swindled by relentless producers is a foregone conclusion in the minds of the consumers.

The ambiguity of a person subject to city living has been accountable for general large scale unjust trade practices thus as a result, ill-informed and unorganized customers have to put up with the burden of violation by the producers and traders through the extensive use of media advertisements.

Haggling over prices it considered an art in our society. The buyer or consumer pits his or her wits against the seller and the sale is fixed at the point where both consider themselves to be justified. Pakistan is considered to be a seller's heaven, being a country of keen shortage. The violation of buyer rights is consequently more obvious in the Third World. Legislation for the defense of consumer rights is as a result quite acceptable. Every state identifies its people as citizens, while the markets take care of people as consumers and rate them as customers. People's civil liberties as consumers are closely related by means of civil rights as citizens they possess; thus the need to support and protect them from the greedy parties in the marketplace.

In order to make the buyers buying decision advertising comes into play, it cajoles the consumer it makes him or her think sympathetically for the product and gives him or her reason to fish into his or her purse and come up with the requisite cash. The consumer guru Eric Clark once said "Advertising is considered necessary to increase helpful information. It has power to cause excessiveness. It can be enjoyable; most of us have certain favorite ads that in fact provoke friendliness. However, it is also a large, influential, extremely gifted and enormously well-to-do business."

In a modern society ideally it is up to the discretion of advertiser/ medium and consumers to make sure that promotion is used astutely and conscientiously. The purchaser plays an energetic function in the advertising progression of events. The consumer looks at advertising message whilst looking for answers to his or her buying tribulations. Advertisements may thus provide a basis of information regarding products, as a guarantee of the product quality. The buyer's approach to a product might alter the reaction to the advertising he is subjected to. Thus the mind of the prospective buyer may go through a multitude of successive stages. The concept of need arousal in the mind of the consumer is very important. The prospective buyer is made to feel and think sympathetically towards the product or service being advertised.

Consumer defined:-

"It is any human being who buys certain product or service for personal use and not for manufacturing or resale. He is someone who has the power to make the final decision whether or 
not to purchase an item at the store and someone who can be predisposed by marketing and advertisements."

A great favour of the buyer is his or her inclination to purchase. In other words we can say that vendor is not giving the consumer any favour by providing the purchase opportunity infect it is the consumer is providing the favour by providing the opportunity to serve them.

All of us are consumers when we set out for the markets. It is our routine that we buy products based on our needs and requirements, but at the same time we are bit concerned over our health, money and environment so we keep all our concerns while purchasing goods. Cheating customers has now become so prevalent that no one remains untouched by it. Wrong advertisements, fake announcements and false discounts victimize the consumers badly. In order to stop this or her victimization concrete steps have to be taken.

\section{Objectives}

This research paper will aim to achieve the following objectives:-

1) This research paper aim to show relevance of consumer behavior to buying activity.

2) This research paper aim to reaffirm that the study of consumer behaviors useful to consumeradvocate groups concerned with designing laws to assist and protect consumers.

3) This research paper aims to study the aspects of consumer's behavior needed in order to resolve the issue raised by violation of consumer rights by TV Channels through advertisements.

4) This research paper aims to get inside information and the study will also aim to get an insight into the violation of consumer rights by the media.

5) This research paper aims to create a better understanding of how the consumer is exploited and this study will also try to understand the reasons of the violation of consumer rights by the media.

6) This research paper aims to review the existing sensitive relationship between the advertisers and the media.

7) The research paper will cover the factors which have led to the commercialization of society by the advertisers.

8) This research paper aims to provide the reader a better and clearer picture of how consumerism is eating away at the moral fabric of our society.

\section{Findings}

The consumer and his or her relationship with the media and its providers is a dicey one. The researcher was able to unearth the following facts by means of this research paper.

1. Consumers are exploited mainly because of their ignorance of law. The only way to ensure this is to educate the consumer on the subject of his or her rights with regards to the subject. 
2. Media is used for airing false claims by the advertiser/producer through advertisement.

3. Media is responsible for creation of arousal need in the consumers.

4. Consumer protection is necessary because of the malpractices, practiced by the dishonest producers, traders, media, etc.

5. Consumer rights are being exploited because of the rampant corruption in the law enforcing machineries.

6. Consumer rights are also exploited because of the existence of a lengthy legal process.

\section{Conclusion}

After numerous visits to offices of the consumer courts, interviews of the staff and a careful analysis of the data it was revealed to the researcher that the violation of consumer rights by the electronic media through advertisements is rampant and unchecked. At the end of my survey the following was revealed.

Results show that the awareness level of the consumers regarding their rights is at its lowest level with $29.5 \%$ whereas in control group this ratio is only $6.0 \%$ which is almost equal to zero.

Low literacy rate is the main hindrance in the way of the violation of consumer rights. All of my respondents were females, most of whom were restricted in getting education by their families. Less educated consumers can easily become the victims of violation. Media can easily trap them through attractive advertisements. To protect the consumer it is necessary to make them educated first and educate them regarding their rights through awareness campaigns by electronic media which has a very strong impact in the daily routine of every person now a days.

NGO's along with the Government can play a vital role in increasing the awareness in consumers. They can give awareness to consumer about their rights. Very few respondents of the control group knew about consumer rights which were provided them by law. According to the results the researcher came to know that awareness of the consumers regarding the laws provided them by the Law for their protection is the first step that should be taken for the consumer protection. The researcher came to know that those respondents who are educated and have more exposure are more aware about their rights.

According to the consumer protection act of Pakistan 2005 the onus of responsibility for the credibility of products lies with the producer/ manufacture only. But the results of this research paper show that a large number of respondents strongly believe that along with producer/ manufacturer onus of responsibility should also lie with the advertising agencies and media for the creation and airing the advertisements. Government is not fulfilling its responsibilities towards advertising. $65 \%$ respondents of the survey answered in favour of this statement. There is much room for improvement required in both the legislation and implementation sectors. As a result the researcher came to know that the responsibilities of the Government regarding the violation of consumer rights by the advertised agencies and media through advertisements is not being fulfilled by the Government and advertiser. Thus it has become a reason of annoyance for both the control and intervention groups. 
Pakistan has its laws regarding consumer protection but after the results of the survey being taken by the researcher for this research paper, it was revealed that consumers are not aware about these laws and those who have awareness are able to proceed. They don't know where they should go to lodge their complaints. There is a need to educate the public about these laws and also to make them aware that how they can proceed if they have any complaint regarding any product. The existing laws for the protection of consumer rights regarding electronic media advertisements are not sufficient. Laws for the prohibition of such advertisements which exploit consumer rights do not exist in the consumer protection act of Pakistan. 65\% respondents of the survey are those who want legislation regarding electronic media advertisements for the protection of the consumers.

During the course of this research paper it was revealed to the researcher that the Pakistani consumer is vulnerable to the attacks of the advertiser and has no savior. It is unfortunate that we have little or no regulations and live in a society which gives no protection to the poor exploited man in the society.

In the light of the research conducted by the researcher the fact that consumer rights are being exploited by the media through advertisements stands validated.

\section{Recommendations}

To allow the consumer to earn his rightful place in society and to give him a decent chance of making the right decision while being barraged daily with the volleys of advertisements being transmitted in the air it is essential that the following be done:

1. Regulations by consumer groups.

2. Consumer awareness programs should be aired by the government.

3. Consumer should understand his responsibilities, and he should report his case to court if the need arises.

4. Consumers should have the courage to protest and knock at the door of the law enforcing machineries.

5. Consumers should have the rights to acquire the knowledge and skill to be informed consumer.

6. Advertisers/producers should have to inform the consumer about the quantity, potency, purity, standard and price of the product.

7. Advertising agencies should be held accountable.

8. Onus of responsibility should also lie with the media who airs the content via its medium.

Having laws in no good till the time they are put into practice. Swift decisions and the backing of offenders is the need of the day. 


\section{References}

Assael, H., (1992), “Consumer Behavior and Marketing Action”. Boston, PWS-KENT.

Baker, R. (1968) “Ecological Psychology”. Stanford, Stanford University Press.

Bovee, L. E., William (1994) “Arens Contemporary Advertising Courtland” $4^{\text {th }}$ Edition.

Booth, S. (1993) Crisis Management Strategies. Routledge, London.

Clark, Eric. (1988) "The Want Makers" "Lifting the lid off the World Advertising Industry" "How They Make You Buy".

Clark, T., (1988) "The Concept of a Marketing Crisis". Journal of Academy of Marketing Science, Summer, pp. 43-48.

Daniel, S. Warner: S; John, (1962) “Wright Advertising”.

Dutton, J. E. and Jackson S. E., (1987), "Categorizing Strategic Issues: Links To Organizational Action”. Academy of Management Review, Vol.12, No.1, pp. 76-90.

Day, R. L. and London, E. L., (1976), "Challenging Comprehensive Consumer Complaint Data by Survey Research", In Andersson, B. B. Advances in Consumer Research 3, (Ed.) Atlanta: Association for Consumer Research, pp. 263-268.

Diamond, S. L. Scott W. and R. Faber., (1976), "Consumer Problems and Consumerism: Analysis of Calls to a Consumer Hot Line". Journal of Marketing, Vol. 40, January, pp. 58-62.

Jain, N.K (2000) "Consumer Protection Law and Practice”.

Keane, J., (1991), “The Media and Democracy”. London, Polity Press and Basil Blackwell Inc.

Mitchell, T. H., (1986) "Coping with a Corporate Crisis". Canadian Business Review, vol. 13, No.3, pp.17-20.

Nilson, T., (1995) Chaos Marketing, London. McGraw-Hill Company.

Richins, M. L., (1983) "Negative Word of-Mouth By Dissatisfied Consumers: A Pilot Study". Journal of Marketing, Winter, Vol. 47, pp. 68-78.

Tory, C. L., (1993) "Consumer Environmental Consciousness: A Conceptual Framework and

Exploratory Investigation”. American Marketing Association, Summer, Vol. 4, pp.106-114. 